Фармакологічні дослідження біологічно активних речовин

Pharmacological researches of biologically active substances

Рекомендована д. біол. наук, профр. Л. С. Фірою

УДК 615.014.22:615.282:616-092.9

DOI

\title{
ВИВЧЕННЯ ПРОТИЗАПАЛЬНОЇ АКТИВНОСТІ ОПРАЦЬОВАНОГО КРЕМУ БЕТАКАРБОКЛОМЕТ
}

\author{
(сАрам Дуллах, І. О. Власенко, Г. М. Войтенко, Л. Л. Давтян \\ Національна медична академія післядипломної освіти імені П. Л. Шупика
}

\begin{abstract}
Резюме: у статті представлені результати вивчення антиексудативної активності опрацьованого крему комплексної дії на основі клотримазолу, бетаметазону дипропіонату, метронідазолу та сечовини для лікування дерматомікозів. Методом in vivo (модель гострого асептичного (декстранового) запалення) встановлено, що опрацьований крем має характерну для глюкокортикоїдів протизапальну активність, динаміка і ступінь якої відповідають дії препарату порівняння.
\end{abstract}

Ключові слова: дерматомікози, бетаметазону дипропіонат, антиексудативна активність.

Вступ. Останні роки характеризуються помітним зростанням захворюваності на грибкові захворювання [1], а мікози стоп займають одне з перших місць захворюваності шкіри [2]. Часто вони характеризуються потовщенням рогового шару стопи, тріщинами та запальним процесом, викликають біль, свербіж [3]. Тривалий перебіг мікологічного прочесу призводить до глибоких порушень діяльності організму, ускладнює перебіг інших захворювань та знижує якість життя хворого [4].

Відомо, що дерматомікози внаслідок запальної та токсичної природи супроводжуються дерматитом як захисною реакцією ураженої шкіри [5]. Тактика сучасної місцевої терапії дерматитів спрямована на обмеження ураженої зони, зменшення запальної реакції; стимуляцію репаративних процесів, відновлення бар'єрних функцій шкіри [6].

Дерматомікози, що супроводжуються запальною реакцією шкіри, доцільно лікувати комбінованим призначенням протигрибкових засобів і кортикостероїдами місцевої дії $[7,8]$. Останні виявляють протизапальну, протисвербіжну, антипроліфреративну та імуносупресивну дію [9].

Перспективним $€$ синтетичний кортикостероїд бетаметазону дипропіонат, що має сильну протизапальну та протиалергійну дії, покращує мікроциркуляцію, знижує проникність судин, викликає вазоконстрикцію капілярів [10].

Маркетингові дослідження фрармацевтичного ринку України дерматологічних лікарських засобів (група D за ATC класифікацією) показали їх значний асортимент. Але багатокомпонентних препаратів, що впливають на всі ланки патологічного процесу, представлено недостатньо [11].

На основі результатів фрармако-технологічних, фрізико-хімічних та біологічних досліджень розроблено м'який лікарський засіб (МЛЗ) комплексної дії на основі клотримазолу, бетаметазону діпропіонату, метронідазолу та сечовини для лікування дерматомікозів, під умовною назвою Бетакарбокломет [12].

Метою дослідження було вивчення антиексудативної активності опрацьованого МлЗ

Методи дослідження. Вивчення антиексудативної активності опрацьованого МЛЗ проводили на моделі гострого асептичного (декстранового) запалення згідно з методичними рекомендаціями [14]. Дослідження проводили на безпородних білих щурах масою 180 - 220 г. Запалення викликали субплантарною ін'єкцією в праву задню стопу щурів 0,08 мл 3 \% водного розчину декстрану.

Ексудативне запалення оцінювали онкометрично, вимірюючи об'єм лапки в динаміці механічним онкометром за А. С. Захаревським [15]. Результати піддавали статистичній обробці.

Об'єм стопи реєстрували до ін'єкції (вихідний рівень), через 1 год (на піку набряку) і через 3, 5 год після ін'єкції фрлогогеном. Протизапальний ефект (А) оцінювали за ступенем інгібування приросту набряку стопи на фроні досліджуваних препаратів порівняно 3 контролем і розраховували за фрормулою:

$$
A=\frac{\left(\Delta V k-\Delta V_{0}\right)}{\Delta V k} \times \cdot 100 \% \text {, }
$$

де $\Delta V 0$ - середній приріст об'єму набряклої стопи у тварин, що лікували, мл;

$\Delta V \kappa$ - середній приріст об'єму набряклої стопи у тварин, що не лікували, мл.

Для проведення математичних розрахунків застосовували стандартний пакет статистичних програм Statistica 6 [16].

Результати й обговорення. У дослідженні дослідні тварини були розділені на 3 групи по 6 щурів у кожній: перша група - тварини, яких лікували опра-

ISSN 2312-0967. Фармацевтичний часопис. 2015. № 3 
Фармакологічні дослідження біологічно активних речовин Pharmacological researches of biologically active substances

цьованим кремом Бетакарбокломет, друга - тварини, яких лікували референтним препаратом, третя - контрольна патологія. Препаратом порівняння слугував комбінований препарат - крем Тріакутан (Корпорація «Артеріум», Україна).

Крем Бетакарбокломет і препарат порівняння наносили на лапу тварини за 1 год до ін'єкції і відразу після ін'єкції фрлогогену. Далі МЛЗ Бетакарбокломет, як і ресрерент-препарат, двічі наносили на шкіру стопи щурів до гомілковостопного суглоба в кількості 100 мг - за 30 хв до і безпосередньо відразу після ін'єкції фрлогогенного агента. Сумарна кількість крему, що наноситься на тіло щура - 200 мг, що з урахуванням середньої маси щурів становить 0,36 мг/кг у перерахунку на бетаметазону дипропіонат.

Результати вивчення протизапальної активності розробленого крему Бетакарбокломет на моделі декстранового набряку наведено та рисунку 1.

Згідно 3 результатами експериментального дослідження (рис. 1), при декстрановому запаленні у нелікованих щурів (контроль) спостерігається швидкий розвиток запального набряку стопи. Механізм декстранового набряку пов'язаний з активацією викиду медіаторів гістаміну і серотоніну, які запускають патологічні зміни в перші години після альтерації [17].

Максимальний приріст об'єму запаленої стопи спостерігали вже через 1 год після введення декстрану, складаючи в середньому 0,78 мл. У наступні 5 год набряк стопи поступово знижувався, але до вихідного об'єму не повернувся.
У ході дослідження виявили, що опрацьований крем володіє вираженою протиексудативною активністю, яка достовірно не відрізняється від референтного препарату. Приріст об'єму лапи тварин, яким наносили лз Бетакарбокломет, склав на піку набряку

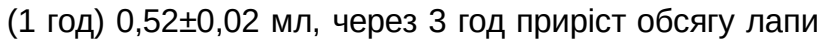
від початкового об'єму склав $(0,36 \pm 0,02)$ мл, а до 5 год - $(0,20 \pm 0,01)$ мл. Середня величина протинабрякової дії опрацьованого МЛ3 за 5 год становила близько $50,98 \%$, а для референтного препарату - 47,47 \%.

Здатність розробленого крему Бетакарбокломет пригнічувати запалення на ранніх стадіях проявилася за рахунок бетаметазону дипропіонату, який, згідно з даними літератури, здатний інгібувати метаболізм ліпо- та циклооксигеназного шляху арахідонової кислоти і в результаті зменшувати синтез простагландинів, простацикліну та ін.; пригнічувати вивільнення еозинофрілами медіаторів запалення; скорочувати викид вільного гістаміну; знижувати проникність мембран; індукувати утворення ліпокортинів, що мають протинабрякову активність [18]. Таким чином, проведене вивчення впливу розробленого крему Бетакарбокломет на процеси запалення дозволяють вважати, що МЛ3 має виражену протизапальну дію (гальмує розвиток серотонінового набряку).

Відмінності між показниками МЛЗ і референтпрепарату не є достовірними, тому можна зробити висновок, що опрацьований крем Бетакарбокломет володіє характерною для глюкокортикоїдів протизапальною активністю, динаміка і ступінь якої відповідають дії препарату порівняння.

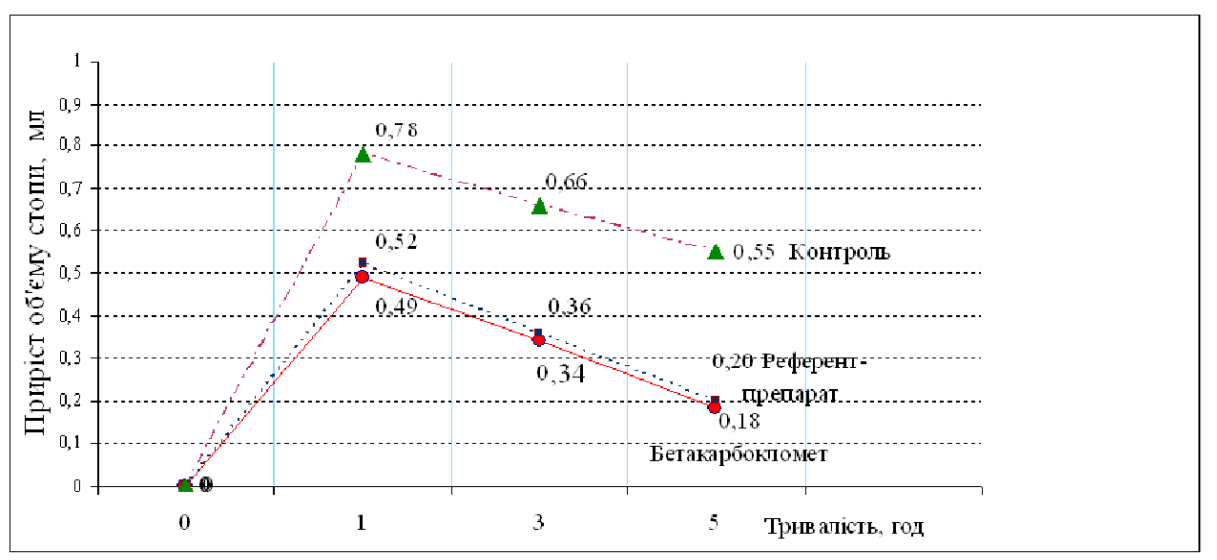

Рис. 1. Динаміка приросту об'єму стопи щурів при аплікаціях дослідних зразків при декстрановому запаленні.

Висновки. На підставі фрармакологічних досліджень при експериментальному запаленні, виклика- ному декстраном, опрацьований лз Бетакарбокломет виявляє протизапальний ефект на рівні прототипу.

\section{Список літератури}

1. Siddiqui A. R. A fungus among us// A. R. Siddiqui, J. M. Bernstein, H. Polenakovik/ Skinmed. - 2010. - Vol. 8 (5). - P. 291-292.

2. Kamimura-Nishimura K. Dermatological conditions in international pediatric travelers: Epidemiology, prevention and management/ K. Kamimura-Nishimura, D. Rudikoff, M. Purswani, S. Hagmann// Travel Medicine and Infectious Disease. - 2013. - Vol. 11, N 6. - P. 350-356.

3. Gupta A.K. Investigational drugs for onychomycosis/ A.K. Gupta, F.C. Simpson// Expert Opinion on Investigational

ISSN 2312-0967. Pharmaceutical review. 2015. № 3 
Фармакологічні дослідження біологічно активних речовин Pharmacological researches of biologically active substances

Drugs. - 2014. - Vol. 23, N 1. - P. 97-106.

4. Перламутров Ю. Н. Микозы стоп, современные аспекты клинико-эпидемиологических характеристик и лечение / Ю. Н. Перламутров, К. Б. Ольховская // Consilium medicum. Дерматология. - 2012. - № 2. - С. 22-26.

5. Stamatas G.N. Early inflammatory processes in the skin/ G.N. Stamatas, A.P. Morello, D.A. Mays// Current Molecular Medicine. - 2013. - Vol. 13, N 8. - P. 1250-1269.

6. Белоусова Т. А. Наружные глюкокортикостероидные препараты: критерии выбора с позиции эффективности и безопасности / Т. А. Белоусова, М.В.Горячкина // Вестник дерматологии и венерологии. - 2010. - № 6. - С. 93-100.

7. Kundu R.V. Dermatologic conditions in skin of color: Part II. disorders occurring predominantly in skin of color/ R.V. Kundu, S. Patterson// American Family Physician. 2013. - Vol. 87, N 12. - P. 859-865.

8. Дерматовенерология. Национальное руководство. Краткое издание. - М. : ГОЭТАР-Медиа, 2013. 896 с. 9. Correa-Fissmer M. Prevalence of self-medication for skin diseases: A systematic review/ M. Correa-Fissmer, A.H. Martins, M.G. Mendonca [et al.]// Anais Brasileiros de Dermatologia. - 2014. - Vol. 89, N 4. - P. 625-630.

10. Коляденко В. Г. Комбинированные препараты группы бетаметазона в лечении аллергодерматозов / В. Г. Коляденко, П. В. Чернышов // Дерматологія. - 2007. - № 1. - С. 31-34.

11. Власенко І. О. Вивчення асортименту лікарських засобів для місцевого лікування грибкових уражень, що ускладнені кератозом / І. О. Власенко, А. Дуллах, Л. Л. Давтян // Фармац. журн. - 2013. - № 6. - С. 15-20.
12. Маркетинговое исследование рынка дерматологических лекарственных средств в Украине / И. А. Власенко, Арам Дуллах, Е. А. Іванов, Л. Л. Давтян // Разработка, исследование и маркетинг новой фрармацевтической продукции: сб. науч. тр. Волгоградский гос. мед. Университет. Пятигорский мед.-срарм институт. - Волгоград, 2014. - Вып. 69. - С. 334-337.

13. Пат. на корисну модель 99794 Україна, А61P 17/00. Емульсійно-суспензійний крем для лікування гіперкератозних дерматомікозів «Бетакарбокломет» / Власенко І. О., Давтян Л. Л., Арам Дуллах, Маньковский Б. М.; - № u2014 13955; заявл. 25.12.2014; опубл 25.06.15, Бюл. № 12.

14. Доклинические исследования лекарственных средств: метод. рекомендации / под ред. А. В. Стефранова. - К. : Авицена, 2002. - 568 с.

15. Руководство по экспериментальному (доклиническому) изучению новых фрармакологических веществ / под ред. В. П. Фисенко. - Москва, 2000. - 398 с.

16. Реброва О. Ю. Статистический анализ медицинских данных. Применение пакета прикладних программ Statistica / О. Ю. Ребров. - 3-е изд. - М.: Медиа Сфрера, 2006. - 312 с. 17. Захаренко В. В. Влияние Пропеса на процессы воспаления / В. В. Захаренко // Вісник морфології. 2013. - T.19. - № 2.- C. 277-280.

18. Schicke H. Characterization of ZK 245186, a novel, selective glucocorticoid receptor agonist for the topical treatment of inflammatory skin diseases/ $\mathrm{H}$. Schicke, T. M. Zollner, W. D. Dicke [et al.]// PediatrDermatol. - 2008. Vol. 2, № 25. - P. 269-270.

\title{
ИЗУЧЕНИЕ ПРОТИВОВОСПАЛИТЕЛЬНОЙ АКТИВНОСТИ РАЗРАБОТАННОГО КРЕМА БЕТАКАРБОКЛОМЕТ
}

\author{
Арам Дуллах, И. А. Власенко, Г. М. Войтенко, Л. Л. Давтян \\ Национальная медицинская академия последипломного образования имени П. Л. Шупика
}

Резюме: в статье представлены результаты изучения антиэксудативной активности разработанного крема комплексного действия на основе клотримазола, бетаметазона дипропионата, метронидазола и мочевины для лечения дерматомикозов. Методом in vivo (модель острого асептического (декстранового) воспаления) установлено, что разработанный крем обладает характерной для глюкокортикоидов выраженной противовоспалительной активностью, динамика и величина которой соответствуют действию препарата сравнения.

Ключевые слова: дерматомикоз, бетаметазона дипропионат, антиэксудативная активность.

\section{STUDY OF ANTIINFLAMMATORY ACTIVITY OF FORMULTATED CREAM BETAKARBOKLOMET}

\author{
Aram Dullakh, I. O. Vlasenko, H. M. Voytenko, L. L. Davtyan \\ National Medical Academy of Postgraduate Education by P. L. Shupyk
}

Summary: the article presents the results of the study of antiexudative activity of complexed antifungal cream, based on clotrimazole, betamethasone dipropionate, metronidazole and urea, for treatment of dermatomycosis. By in vivo method (model of acute aseptic (dextran) inflammation) it was found that the formulated cream has antiinflammatory activity typical for glucocorticoids, dynamics and the value of which correspond to the activity of referent-medicine.

Key words: dermatomycosis, betamethasone diptopionate, antiexudative activity.

Отримано 12.05.2015

ISSN 2312-0967. Фармацевтичний часопис. 2015. № 3 